Chapman University

Chapman University Digital Commons

Education Faculty Articles and Research

Attallah College of Educational Studies

$12-14-2018$

\title{
Conceptualizing Equity in the Implementation of California Education Finance Reform
}

Taylor N. Allbright

Julie A. Marsh

Michelle Hall

Laura Tobben

Lawrence O. Picus

See next page for additional authors

Follow this and additional works at: https://digitalcommons.chapman.edu/education_articles

Part of the Educational Administration and Supervision Commons, Educational Assessment, Evaluation, and Research Commons, and the Educational Leadership Commons 


\section{Conceptualizing Equity in the Implementation of California Education Finance Reform}

\section{Comments}

This article was originally published in American Journal of Education, volume 125, issue 2, in 2019. DOI: $10.1086 / 701247$

\section{Copyright}

University of Chicago Press

\section{Authors}

Taylor N. Allbright, Julie A. Marsh, Michelle Hall, Laura Tobben, Lawrence O. Picus, and Magaly Lavadenz 


\title{
Conceptualizing Equity in the Implementation of California Education Finance Reform
}

\author{
TAYLOR N. ALLBRIGHT and JULIE A. MARSH \\ University of Southern Califormia \\ MICHELLE HALL \\ Chapman University \\ LAURA TOBBEN \\ University of California, Berkeley \\ LAWRENCE O. PICUS \\ University of Southern California \\ MAGALY LAVADENZ \\ Loyola Marymount University
}

We examine how district administrators' conceptions of equity relate to the implementation of finance reform. We use sensemaking theory and four views of equity - libertarian, liberal, democratic liberal, and transformative - to guide a case study of two districts, finding evidence of two conceptions of equity: (1) greater resources for students with greater needs and (2) equal distribution of resources for all students. One district demonstrated an organization-wide belief in the first conception, whereas the other conveyed individual-level understandings of both conceptions. These beliefs were mirrored in resource allocation decisions and informed by districts' student demographics, organizational identities, and perceptions of adequacy.

Although state and federal policies have made progress toward goals of equity and adequacy in K-12 education (Odden and Picus 2014), students from traditionally marginalized backgrounds continue to have limited access to

Electronically published December 14, 2018

American Journal of Education 125 (February 2019)

(C) 2018 by The University of Chicago. All rights reserved.

0195-6744/2019/12502-0002\$10.00

FEBRUARY 2019

173 
school funding (Baker and Green 2005; Darling-Hammond 2004), teaching quality (Goldhaber et al. 2015), and rigorous curriculum (Lakes and Donovan 2017; Solórzano and Ornelas 2002) compared with their more privileged peers. Students of color, English learners (ELs), and low-income (LI) students may also encounter biased expectations and a lack of culturally and linguistically appropriate skills among school staff (Gándara and Rumberger 2009; McKown and Weinstein 2008; Ng et al. 2007; Pettit 2011). Such disparities in resources and processes are mirrored in persisting gaps in educational outcomes by socioeconomic status, race, and EL designation (Center for Education Policy Analysis 2018; National Center for Education Statistics 2017; Reardon 2011; Umansky 2016).

TAYLOR N. AlLBRIGHT is a $\mathrm{PhD}$ candidate in the urban education policy program at the University of Southern California's Rossier School of Education. Her research draws on political and organizational lenses to examine the design and implementation of equity-oriented policies in $\mathrm{K}-12$ education. JULIE A. MARSH is a professor of education policy at the University of Southern California's Rossier School of Education. Her research focuses on the implementation and effects of $\mathrm{K}-12$ accountability, finance, and instructional reform policies, including the roles of central office administrators, intermediary organizations, and community members in educational reform and the use of data to guide decision making. MiCHELLE HALL is the director of program assessment and improvement at the Donna Ford Atallah College of Educational Studies at Chapman University. Her research considers the politics and finance of public education with a specific focus on equity and accountability reforms, governance, and community engagement. LAURA TOBBEN is a PhD candidate in the Graduate School of Education at the University of California, Berkeley. Her research examines the intersection between state policy and local implementation with a focus on $\mathrm{K}-12$ initiatives related to equity, accountability, and teacher professionalization. LAWRENCE O. PICUS is the Richard C. Cooper and Mary Catherine Cooper Chair in Public School Administration, a professor of education finance and policy, and the associate dean for research and faculty affairs at the University of Southern California's Rossier School of Education. His research focuses on equity and adequacy of funding for schools and the linkages between education funding and student outcomes. MAGALY LAVADENZ is professor and founding executive director of the Center for Equity for English Learners in the School of Education at Loyola Marymount University. Her research addresses the intersections and impact of policies and practices for culturally and linguistically diverse students, their teachers, and school leaders. 
While prior research has demonstrated the need to redesign school funding to address systemic inequity, only a few studies (e.g., Malen et al. 2015) examine the local implementation of equity-based funding models (Odden and Picus 2014). We address this gap by examining California's Local Control Funding Formula (LCFF), an education finance reform intended to foster equity alongside local flexibility and democratic engagement. Adopted in 2013, LCFF provides districts with base grants and additional differentiated funding for three specific student groups: foster youth (FY), EL, and LI students. ${ }^{1}$ California governor Jerry Brown praised the equity goals of the LCFF, declaring, "Equal treatment for children in unequal situations is not justice" (Strauss 2013). The realization of these equity goals relies heavily on local actors and their interpretation of the policy. This article explores the question, How did district administrators' conceptions of equity shape the implementation of the LCFF? Specifically, how did district actors define equity in the context of LCFF implementation? How did they allocate resources received through the LCFF? And what is the relationship between actors' conceptions of equity and their allocation decisions?

By shedding light on the local-level interpretations that influence the realization of equity goals, this study contributes to our understanding of how actors make sense of finance policies and generates implications for policy makers seeking to implement similar reforms. In the next sections, we discuss the evolution of education finance reforms and the policy context of the LCFF, describe the conceptual framework of sensemaking and perspectives on equity, and present our research design and findings. We conclude with a discussion of these findings and implications for policy and research.

\section{Education Finance and the LCFF}

Historically, American public schools were financed by local districts through property taxes, a practice that resulted in disparities between affluent districts with high tax bases and their less affluent peers. These socioeconomic disparities are also racialized as a result of segregation in schools and housing (Gándara and Aldana 2014; Orfield and Frankenberg 2014). In the twentieth century, state policies and court cases focused on remedying these disparities by seeking equal per-pupil funding, or "horizontal equity" (Corcoran and Evans 2008; Ladd et al. 1999; Odden and Picus 2014). By the late twentieth century, states began to provide weighted formulas that offered more or less funding to districts based on the characteristics of the students they served, an approach termed "vertical equity" (Ladd et al. 1999; Odden and Picus 2014). The standardsbased accountability movement of the 1990s and 2000s emphasized high performance for all students, prompting state finance reforms to stress goals of 
adequacy or resource distributions that allow all students to meet performance thresholds (Ladd et al. 1999; Odden and Picus 2014). ${ }^{2}$

In California's Serrano rulings of the 1970s, the plaintiffs argued successfully that variations in per-pupil revenues, linked to disparities in district wealth, led to unequal educational opportunities for students; as a result, the state was charged with neutralizing interdistrict funding inequities. School finance was further centralized at the state level through the passage of two state ballot measures: 1978's Proposition 13, which cut property taxes (Sonstelie et al. 2000), and 1988's Proposition 98, which mandated a minimum percentage of the state budget for K-14 education (Manwaring 2005). Some researchers argue that efforts to equalize school district revenues in response to Serrano lead to a leveling down of resources - providing fewer resources to affluent districts and maintaining resource allocations for LI districts (Fischel 1996; Silva and Sonstelie 1995). Passage of Proposition 13 likely continued this trend (Sonstelie 2001). In response to demands to meet the needs of diverse students, the state legislature passed over 60 individually funded categorical programs, each designed to serve the needs of unique student populations (Rose et al. 2010).

By the 2000s, many argued that California's finance system was overly complex and opaque, denying local districts the flexibility they needed to respond to the demands of state and federal accountability policies (Hall 2016; Kirst et al. 2007; Weston 2011). In addition, Californians' beliefs about school funding had expanded beyond the horizontal equity of Serrano to include vertical equity to meet varied student needs. In 2012, voters elected a governor who supported vertical equity and argued for "subsidiarity," the principle that the state should only perform tasks that could not be accomplished at the local level (Strauss 2013). The new governor was willing to put all of his political capital behind reforming the state finance system (Hall 2016). As a result, the legislature passed LCFF in 2013.

The LCFF represented a major shift in state policy. First, it adopted a new student-based funding formula, allocating to local education agencies (LEAs) a base grant determined by the size and grade levels of the student population and two additional funding sources: (1) 20\% above the base amount in supplemental grants to districts for each student who qualifies as FY, LI, or EL and (2) an additional $50 \%$ of the base grant in concentration grants to districts serving unduplicated student head counts of above $55 \%$. Second, the law eliminated the majority of categorical programs and devolved authority over how the preponderance of education dollars are spent to LEAs, under the leadership of local school boards. ${ }^{3}$ The state instructs LEAs to determine the use of LCFF dollars through the development of local control accountability plans (LCAPs), created with input from education stakeholders, including parents, students, educators, and community members. In accordance with eight state-prioritized goals, LCAPs must comply with regulations and set accountability standards for 
student outcomes based on multiple metrics (complemented by an emerging state accountability system). ${ }^{4}$

Embedded in LCFF is the idea that students with greater academic needs require additional resources. The inclusion of supplemental and concentration grants was intended to ensure that FY, EL, and LI students gain access to the high-quality teachers, programs, and materials they need to succeed and that this approach to funding would ultimately promote more equitable outcomes. By leveling the playing field for targeted groups, local control was intended to provide fiscal flexibility to districts. LCFF is intended to facilitate decisions tailored to the needs of targeted student groups and local stakeholders, rather than the preferences of state-level policy makers and interest groups, fostering accountability to local communities. ${ }^{5}$

\section{Conceptual Framework}

We draw on sensemaking theory (Spillane et al. 2002; Weick 1995; Weick et al. 2005) to better understand how local district actors interpret and implement California's LCFF. To grasp how actors' understanding of equity in particular informs this sensemaking process, we are guided by literature that considers multiple conceptions of equity (Bertrand et al. 2015; Dowd and Bensimon 2015; Guiton and Oakes 1995) and by Ching (2017), who combines sensemaking and equity conceptions to examine policy implementation in California community colleges. In the next sections, we present a typology of four perspectives on equity and then describe the sensemaking framework used to guide the research design.

\section{Conceptions of Equity}

Equity is often cited as an important goal of education policy reforms (Odden and Picus 2014), yet the term "equity" is ambiguous (Unterhalter 2009). We identified four perspectives on equity in our review of the literature. We draw on Guiton and Oakes (1995) to define three of these approaches, libertarian, liberal, and democratic liberal (see also Bulkley 2013), and we contribute a fourth, the transformative view (Dowd and Bensimon 2015). These perspectives can be understood through their consideration of inputs, such as finances and staff; processes, such as pedagogical strategies; and outcomes, such as test scores. Each of these views considers horizontal (equal) and vertical (unequal) distributions of resources, but they differ in the principles that determine vertical dimensions of equity.

The libertarian perspective (Guiton and Oakes 1995) prioritizes fair competition with equal rules for everyone. ${ }^{6}$ In this view, inputs should be distributed 


\section{Equity in California Education Finance Reform}

equally, unless one demonstrates, through a fair process, that they merit greater resources: for example, students with high test scores might be placed in a gifted program with more highly skilled teachers. Outcomes are expected to be unequal and reflective of individual talent and effort (Herrnstein and Murray 2010).

The liberal stance (Guiton and Oakes 1995; Rawls 2009) assumes that societal disadvantages, particularly in socioeconomic status (Bertrand et al. 2015), must be addressed to level the playing field. Inputs and processes, then, should seek to provide equal opportunity regardless of one's position in society. The liberal view seeks vertical equity to provide more resources to those considered disadvantaged and horizontal equity to ensure that individuals with the same background have the same resources. Like the libertarian perspective, the liberal view expects unequal outcomes reflective of merit. Governor Brown's statements regarding the targeted funding of LCFF suggest that the LCFF reflects a liberal stance.

The democratic liberal view prioritizes outcomes, arguing that all individuals should be supported in achieving a universal threshold of performance, such as the mastery of high academic standards (Guiton and Oakes 1995). Vertical equity should therefore provide additional support for students who are struggling to meet performance expectations. As argued by Odden and Picus (2014), adequacy of education finance should be designed to support these goals. The democratic liberal position emerged from arguments that all students need the skills to participate in democratic society (Dewey 1929; Gutmann 1987). With the influence of standards-based accountability, this position has shifted toward an emphasis on measurable outcomes and the economic returns of education (Mehta 2013). The LCFF's emphasis on applying differentiated inputs to promote improvement in state-mandated educational outcomes evokes a democratic liberal view; however, LCFF lacks the democratic liberal focus on adequacy.

In the transformative view, equity means challenging oppression, including racism and classism (Dixson and Rousseau 2005). This perspective suggests that oppression is perpetuated through structural practices, such as racial disproportionality in discipline (Anyon et al. 2016) or course placement (Oakes and Guiton 1995), as well as educators' implicit biases and expectations (Warikoo et al. 2016). This view also assumes intersectionality: individuals possess multiple social identities, and an understanding of oppression must consider the interactions among the dynamics of race, national origin, class, gender, language, ability, and other constructions (Crenshaw 1991; Solórzano and Bernal 2001). Thus, vertical equity should distribute resources that promote the empowerment of students harmed by the dynamics of power and privilege (Solórzano and Yosso 2002). Rather than focusing on students' deficits, the transformative position views marginalized youth as "holders and creators of knowledge" (Bernal 2002, 106) who possess strengths not acknowledged in the dominant culture (Harper 
and Davis 2012; Yosso 2005), and developing these strengths fosters equitable outcomes (Gonzalez et al. 1995; Kana'iaupuni et al. 2017).

The administrators charged with carrying out LCFF may carry assumptions associated with one or more of these equity stances. In the following section, we discuss how sensemaking theory helps us understand how actors' conceptions of equity shape policy implementation.

\section{Sensemaking}

Sensemaking theory considers how actors embedded in organizational and environmental contexts make meaning of events and use this meaning to inform action (Weick et al. 2005). Sensemaking is the constant, ongoing interaction of three elements: actors' cognitive structures, such as beliefs about equity; actors' situations, including organizational and social context; and events, such as a policy reform (Spillane et al. 2002). To make meaning of events, actors draw on schemas, structures of knowledge and concepts developed through prior experiences to link new information to familiar understandings; and individuals may hold multiple and conflicting schemas simultaneously (Piaget and Inhelder 1969; Spillane et al. 2002). Schemas and interpretations are situated within a broader organizational and environmental context: social interactions (Coburn 2001; Weick et al. 2005), organizational identities and norms (Spillane et al. 2002; Weick 1995), and societal dynamics of power and privilege (Mills et al. 2010) shape actors' sensemaking processes. Thus, actors' conceptions of equity, which are informed by organizational and social context, are expected to shape and be shaped by their interpretation and enactment of policy reform.

Scholars have frequently drawn upon sensemaking theory to examine education policy implementation, particularly in the areas of instructional reform (e.g., Allen and Penuel 2015; Coburn 2001, 2006; Spillane 2000), evaluation (e.g., Halverson et al. 2004; Ingle et al. 2011; Rigby 2015), and data use (e.g., Bertrand and Marsh 2015; Cho and Wayman 2014; Farrell and Marsh 2016; Park and Datnow 2017; Spillane 2012). Collectively, this literature indicates that educators' policy responses are largely driven by their prior knowledge, beliefs, and values, often resulting in implementation variation. Others have applied this lens to the study of education leaders' problem-solving (Sleegers et al. 2009) and how they think about race and social justice (DeMatthews 2015; Evans 2007). In this article, we blend these approaches and extend this lens to analyze district administrators' responses to equity-oriented finance policy. This study provides an opportunity to more explicitly understand the ways in which leaders conceive of equity and how that understanding relates to resource allocation practices.

FEBRUARY 2019 
Equity in California Education Finance Reform

Method

We draw from a larger multiple case study of LCFF implementation in seven local educational agencies the 2016-17 school year (see Humphrey et al. 2017). During the broader study, we found variation in the way participants defined equity in their discussion of resource allocation decisions. Of the seven cases, leaders in Sage School District appeared to be the most aligned with LCFF's liberal equity mandate, whereas those in Annatto School District were the least aligned. Guided by sensemaking theory, which suggests that implementers' beliefs inform policy interpretation and enactment, we selected these two case districts for this study due to their contrast in equity conceptions.

\section{Case Study Districts}

Sage and Annatto School Districts (pseudonyms) are both midsized urban districts in California with majority-Latinx student populations, situated in cities characterized by racial and socioeconomic segregation. Sage's privileged neighborhood is wealthier and whiter than the equivalent in Annatto: Sage's affluent area is approximately $60 \%$ white, $20 \%$ Asian, and $15 \%$ Latinx, with a median household income of more than \$130,000; Annatto's is about 35\% white, 20\% Asian, and 40\% Latinx, with a median household income of about $\$ 80,000 .^{7}$

Table 1 illustrates the districts' student demographics. For the purposes of LCFF, Annatto has an unduplicated count of $75 \%$ and is eligible for both supplemental and concentration LCFF grants. Sage, with an unduplicated count of $50 \%$ due to a lower percentage of LI students, is eligible for supplemental funds only. Compared with Sage, Annatto's unduplicated students are distributed more evenly throughout the district. None of Annatto's schools fall in the low-unduplicated category (defined as less than 30\% unduplicated students). About two-thirds of Annatto's schools are in the high-unduplicated category, with over $70 \%$ unduplicated students. In contrast, $15 \%$ of schools in Sage are in the low-unduplicated category while roughly half the schools are in the high-unduplicated category. This results in a clear distinction between schools with high and low unduplicated counts in Sage, whereas Annatto's schools with the lowest unduplicated count still serve a considerable number of target students.

Table 2 shows the districts' per-pupil funding and changes since LCFF implementation. Student enrollment declines have proportionally decreased state allocations, which are determined by average daily attendance. Despite this enrollment decline, Annatto's funding increased by approximately $27 \%$ due to increased state income and LCFF's supplemental and concentration 
TABLE 1

Case District Descriptive Statistics

\begin{tabular}{lrr}
\hline & Sage & Annatto \\
\hline Total enrollment & 35,200 & 20,200 \\
Student race/ethnicity (\%): & 55 & 82 \\
$\quad$ Hispanic or Latino & 23 & 8 \\
White & 15 & 6 \\
$\quad$ Asian, Filipino, Pacific Islander & 3 & 3 \\
African American & 3 & $<1$ \\
Two or more races & $<1$ & $<1$ \\
American Indian & & 73 \\
LCFF-targeted students (\%): & 46 & 20 \\
Low-income student & 24 & $<1$ \\
English learner & $<1$ & 75 \\
Foster youth & 50 & 67 \\
Overall unduplicated students & & 33 \\
Schools by \% unduplicated students: & 49 & 0 \\
High ( $>70 \%$ unduplicated) & 37 & \\
Medium (30\%-70\% unduplicated) & 14 & \\
Low $(<30 \%$ unduplicated) & & \\
\hline
\end{tabular}

SOURCE.-California Department of Education, district websites, EdData.org.

NOTE.--Numbers have been changed to protect anonymity, but basic proportions and scale remain true. There are approximately 50 charter schools in Sage not included in this table.

grants. Even though Sage does not receive a concentration grant, its funding also increased at a similar rate due to substantially higher property tax revenues. This currently amounts to $\$ 275$ more per pupil in LCFF funding as compared with that of Annatto. As a result, even with the liberal equity intent of LCFF, we find that Annatto, a district with 25\% more unduplicated students, continues to lag in per-pupil funding compared with Sage, a district with more local resources - a difference that may be reflective of broader patterns between districts in affluent and less affluent communities (Hansen et al. 2008). These demographics and funding levels are key contextual factors informing sensemaking processes in each district.

\section{Data and Analysis}

To understand how district actors conceptualized equity and allocated resources, we draw on semistructured interviews with 33 district actors, as shown in table 3. Interview findings were triangulated using district documents, including LCAPs and websites. We selected our participants based on analysis from the broader study, which indicated that district superintendents, high-level central office 
Equity in California Education Finance Reform

TABLE 2

Case Districts' 2016-17 Per-Pupil Funding and Sources

\begin{tabular}{lrr}
\hline & Sage & Annatto \\
\hline Enrollment change pre-post LCFF (\%) & -2 & -5 \\
Revenue change pre-post LCFF (\%) & +25 & +27 \\
LCFF funding (\$) & 3,290 & 7,840 \\
Additional local property tax revenue $(\$)$ & 6,320 & 1,540 \\
Federal revenue (\$) & 510 & 645 \\
Other state revenue $(\$)$ & 1,555 & 1,750 \\
Other local revenue $(\$)$ & 555 & 180 \\
\cline { 2 - 2 } Total per-pupil revenue $(\$)$ & 12,230 & 11,955 \\
\hline
\end{tabular}

SOURCE.-California Department of Education, district websites, EdData.org.

NOTE.- Numbers have been changed to protect anonymity, but basic proportions and scale remain true. All pre-LCFF data were collected from the 2012-13 school year and all post-LCFF data were collected from the 2015-16 and 2016-17 school years. Data prior to 2012 were not included, as California was in a recession during this time. Federal revenue includes all money received from ESSA, plus federal special education and other federal programs. Other state revenue includes lottery and remaining state categoricals (e.g., K-3 class size reduction, state special education, and economic impact aid). Other local revenue includes interest, donations, reimbursements, parcel taxes, rents and leases, and other local sources.

administrators, the school board, teachers' union leaders, and principals were the actors interpreting LCFF and enacting resource allocations. The interview protocol included questions about district goals, the process of resource allocation decisions, the use of LCFF funds, and the extent to which LCFF advanced equity in the district. When interviewees mentioned equity, we probed on the definition of the concept. Interviews lasted approximately 1 hour and were audiorecorded and transcribed.

Interview transcripts were uploaded to NVivo for analysis. We first deductively analyzed the data using a start list of codes derived from our conceptual

TABLE 3

Interview Participants by District and Role

\begin{tabular}{lcc}
\hline & Sage & Annatto \\
\hline Superintendent & 1 & 1 \\
Central office administrator & 9 & 8 \\
School board member & 2 & 2 \\
Principal & 3 & 5 \\
Teachers' union president & 1 & 1 \\
\cline { 2 - 3 } Total participants & 16 & 17 \\
\hline
\end{tabular}

182 American Journal of Education 
framework (Miles and Huberman 1994); we next used inductive, open coding, followed by axial coding (Saldaña 2013) to sort our open codes into categories. We used reflective memos and matrices (Miles and Huberman 1994) to develop our findings regarding district actors' equity conceptions and key factors influencing these conceptions.

To understand resource allocation decisions, we closely analyzed each district's budget and LCAP for the 2016-17 school year, and we compared these documents with the district budgets from 2012-13, the year prior to LCFF. To examine resource allocation at the school level, as school-level budgets are not publicly available, we focused our analysis on staffing before and after LCFF implementation. We used data from the California Department of Education to identify schools with high $(>70 \%)$, medium $(30-70 \%)$, and low $(<30 \%)$ counts of unduplicated students during the 2016-17 year. Henceforth, we refer to these categorizations as high-unduplicated, mid-unduplicated, and low-unduplicated schools. For each district, we selected one school at the high, middle, and elementary levels that reflected each of the three categories, for a total of nine Sage schools and six Annatto schools, as Annatto did not have any low-unduplicated schools to include in this analysis. We used each school's student enrollment, teacher, administrator, and pupil services (e.g., counselors) counts for 2012-13 and 2016-17 to calculate the student-to-staff ratios and the ratio change before and after LCFF.

After completing analysis of interviews and resource allocations, our team reviewed the findings from these two approaches and identified relationships among the findings, noting areas where interviewees' perceptions aligned with or diverged from the resource allocation data. We then revised the findings for each section in light of these relationships across data sources.

\section{Limitations and Trustworthiness}

Our case study has several limitations. As achieving external validity is not the purpose of case study methodology (Yin 2014), our findings are not generalizable to all districts engaged in finance reform; they are instead "an opportunity to shed empirical light about some theoretical concepts" (Yin 2014, 40). Our goal is not to understand the prevalence of particular equity conceptions; rather, we seek to understand the ways in which a particular conception relates to implementation. Aiming for "theoretical replication" (Yin 2014, 57), or an expected contrast in findings, we selected districts that represented stark differences in equity conceptions and, from the perspective of sensemaking theory, would be expected to have diverging interpretations and enactments of LCFF. It is possible that these districts do not represent a typical implementation of California's finance reform. Furthermore, case study methodology cannot verify causality; we do not make 
claims regarding whether an equity conception caused a particular resource allocation decision. It is possible that the act of allocating resources may inform district actors' beliefs about equity, or these concepts may reflexively shape one another.

This article focuses on the relationship between local actors' beliefs and resource allocation decisions, yet it is important to acknowledge that other factors beyond the scope of our analysis, such as political pushback (Trujillo 2013) or organizational structure (Honig et al. 2017), may also enable or constrain district policy implementation. In addition, by bounding our analysis to district actors' equity conceptions, we excluded the perspectives of families and students, who, as stakeholders in LCFF's local accountability process, carry their own equity conceptions that may influence resource allocations.

To ensure the trustworthiness of our findings, the researchers examining the conceptions of equity and resource allocation decisions worked separately to avoid biasing one another's analysis. For the interview analysis, two researchers coded data separately and then conducted a peer debriefing to identify points of convergence and divergence in our analysis. When findings emerged, we reexamined the data in an active search for disconfirming evidence. Throughout the study, we maintained reflexive awareness regarding the influence of our identities and beliefs on our research (Peshkin 1988). As members of elite universities and as a predominantly white research team, we made a particular effort to notice ways in which our own conceptions of equity and dynamics of power and privilege might shape our work (Gordon 2005): we explicitly discussed how our own conceptions of equity and positionalities may have influenced our findings, used written memos to reflect on these influences during data analysis, and provided feedback regarding possible biases during the drafting process.

\section{Results}

Overall, our analysis revealed that district actors' LCFF resource allocations mirrored their conceptions of equity, and this process was related to district context. In Sage, a perception of adequate per-pupil funding, a coherent organizational identity, and the presence of several low-unduplicated schools were key factors supporting a clear conception of equity as greater resources for students with greater needs - a view reflected in decisions to differentiate staffing. In Annatto, the perception of inadequate per-pupil funding, an organizational identity of division, and the absence of low-unduplicated schools were among the key factors informing two competing equity conceptions: greater resources for greater needs and equal resources for all students. The presence of these two conceptions aligns with Annatto's approach of allocating most resources district- 
wide while also differentiating some resources for the schools with the highest number of unduplicated students.

Next we describe district actors' conceptions of equity, how these conceptions were mirrored in their resource allocation decisions, and the key factors that informed these conceptions and decisions.

\section{District Actors' Conceptions of Equity}

Table 4 depicts the extent to which district actors' equity ideas reflected libertarian, liberal, democratic liberal, and transformative perspectives. In Sage, all interviewees presented a liberal conception of distributing resources to compensate for societal disadvantage; in Annatto, the majority (13 of 17) of district actors expressed this view. No interviewees in Sage presented libertarian ideas; in contrast, over half (10 of 17) of Annatto interviewees described libertarian principles of distributing resources equally regardless of student background. In both districts, several interviewees described equity as closing outcome gaps or high academic achievement, reflecting a democratic liberal view. In Annatto, one interviewee defined equity as creating a positive school climate for LI students, which might represent a transformative view of addressing issues of classism in schools.

Interviewees predominantly discussed equity in relation to inputs (funding and staff), though several interviewees in each district also defined equity through processes or outcomes. Regarding the financial inputs of LCFF in particular, interviews with district actors revealed two conceptions of equity, illustrated in table 5. These conceptions included (1) equity requires greater resources for students with greater needs, and (2) equity requires the equal distribution of resources for all students. Sage participants expressed an organizational belief in conception 1, while Annatto participants expressed variation in individual-level equity understandings.

Equity conception 1: Greater resources for greater needs.-Participants in both districts defined equity as the distribution of resources based on need, with "need"

TABLE 4

Number of Participants Expressing Ideas Associated with Equity Perspectives

\begin{tabular}{lcccc}
\hline & Libertarian & Liberal & Democratic Liberal & Transformative \\
\hline Sage $(n=16)$ & 0 & 16 & 4 & 0 \\
Annatto $(n=17)$ & 10 & 13 & 5 & 1 \\
\hline
\end{tabular}

NoTE.-Individual participants may have expressed ideas associated with more than one equity perspective. 
Equity in California Education Finance Reform

TABLE 5

Number of Participants Expressing Input-Related Equity Conceptions in Interviews

\begin{tabular}{lccc}
\hline & $\begin{array}{c}\text { Greater Resources for } \\
\text { Greater Needs (Only) } \\
(1)\end{array}$ & $\begin{array}{c}\text { Equal Resources } \\
\text { for All (Only) }\end{array}$ & Both 1 and 2 \\
\hline Sage $(n=16)$ & 16 & $(2)$ & 0 \\
Annatto $(n=17)$ & 6 & 4 & 7 \\
\hline
\end{tabular}

broadly defined as membership in one of the LCFF targeted groups. Contrary to these LCFF definitions of target groups, however, several participants in each district added that students in special education should be considered high-needs students, and one participant in Annatto argued that Latinx students were in need of greater resources. This overall conception aligns with the liberal position on need-based vertical equity (Guiton and Oakes 1995) and mirrors the intent of LCFF as expressed by Governor Brown (Strauss 2013). All interviewees in Sage expressed this understanding and indicated that this was a district-wide belief. The superintendent explained, "Here we talk about giving each student what they need, not an equal amount of money or service or dollar. It's really about providing for every student, what they need to be successful." A Sage principal suggested that anyone who disagreed with this understanding of equity work elsewhere: "I think that it's easy for me to say what I'm saying because I believe in it but it's also the belief system at central office level as well ... why would you be in education if you don't believe in using the money for a needy group of kids? ... Maybe you aren't a good fit for our district, and good luck. Somewhere else."

Most Annatto participants also expressed the conception of equity as greater resources for greater needs; however, interviewees presented this understanding as an individual rather than an organizational definition. As the Annatto superintendent told us, "And to me, correct me if I'm wrong, I've told my board members, I don't define equity as equal. If I gave everybody a pair of glasses, that's equal. But equity is I give you glasses because you need glasses" (emphasis added). An administrator described the challenge of convincing other district actors to support this definition: "I think that's a hard thing for some people and in some of the trainings we're doing ... around equal and equity being, something being equal and something being equitable. There is this piece that if one student gets it, everyone should get it ... it's really hard to shift some of those kinds of deep seated beliefs." Interestingly, half of interviewees in Annatto presented this view simultaneously with the next, competing conception: equal resources for all.

Equity conception 2: Equal resources for all students.-Though no participants in Sage articulated an "equity as equal" conception, over two-thirds of the participants in Annatto expressed equity as distributing resources equally to meet all students' basic educational needs, relating to the libertarian and liberal emphases 
on horizontal equity (Guiton and Oakes 1995; Ladd et al. 1999). Notably, interviewees articulated the need to equalize school funding between schools with and without Title I funding. Several administrators argued that there was a similar basic need among all students in both mid- and high-unduplicated schools and that all schools in the district should thus receive equal resources. In the words of the Annatto superintendent: "Title I is really the equalizer or the un-equalizer because schools in [North Annatto] are mostly Title I. So they still have the added benefit of they can do a lot more because they have Title I funds, but the [South Annatto] schools don't get Title I, but then LCFF we try to equalize and give them everything they want." A principal echoed this point: "It [LCFF] seems like reverse equity, because the [South Annatto] side is not Title I. So, when people think of equity they think of the underserved ... But then you come to living in the [South Annatto] side, our students are just as in need as the students in [North Annatto].... So in terms of equity I feel that that is being balanced by giving more to the [South Annatto] that has been done in the past so that it can equalize itself." Thus, while Sage expressed a singular, organizational understanding of liberal vertical equity, Annatto interviewees described individual-level understandings of both vertical and horizontal equity principles.

Equity in outcomes.- In describing equity in the context of LCFF implementation, participants primarily focused on the equitable distribution of inputs. However, five participants in each district noted that equity required closing gaps in test scores or increasing college attainment, illustrating a performance focus in alignment with democratic liberal beliefs. Interviewees in both districts noted a lack of outcome data needed to evaluate input decisions. The Sage teachers' union president explained, "We can plan and implement all the inputs ... but the capacity to analyze the outcome in a way that's meaningful as opposed to a broad snapshot of the district ... is far beyond us." An Annatto administrator similarly noted, "We provide [services to targeted students]. How much of that is increasing student achievement? ... How are they doing, GPA, attendance, on state standardized tests?"

In sum, actors presented two understanding of equity in relation to inputs: greater resources for greater needs or equal resources for all students. About a third of participants in each district also emphasized equitable outcomes on achievement tests and in college attainment, though there were concerns regarding the lack of outcome data needed to inform the distribution of inputs. In the next section, we examine how these conceptions ultimately shaped resource allocation decisions.

\section{Resource Allocation Decisions Mirrored Equity Conceptions}

Overall, these differences in conceptions of equity mirrored the pattern of resource allocation across the two districts. District leaders in Sage chose to redis- 
tribute some resources away from low-unduplicated toward high-unduplicated schools. In contrast, district leaders in Annatto chose to distribute large portions of LCFF funds to all schools; however, Annatto also made some targeted investments in high-unduplicated schools. As noted earlier, school-level differences in unduplicated counts are greater in Sage than in Annatto. Thus, when Sage district leaders described reallocating funding away from their low-need schools toward their high-need schools, they were describing a shift in dollars away from schools with substantially lower concentrations of unduplicated students toward schools with much higher concentrations of unduplicated students. Next we examine these patterns in greater detail.

LCFF resource allocation in Sage: Targeted staffing.-In Sage LCFF allocations primarily supported additional administrative and support staff in highunduplicated schools, mirroring their definition of equity as greater resources for students with greater needs. Sage administrators used the majority of LCFF supplemental funds (as noted earlier, Sage did not receive concentration funds) to invest in instructional personnel attached to schools with the highest unduplicated count. Endorsing their focus on staffing, the superintendent explained, "The best training and the curriculum in the hands of the wrong individuals isn't going to make a difference for kids." In Sage's strategic plan and LCAP, the district identified its goal of structuring staffing allocations to ensure that supplemental funds were directly serving targeted students. "We're spending supplemental resources with the equity philosophy," said one top official, who later added, "it is just not going in the traditional way, where it's spread equally to everybody.... I think that's unique here.... It's a shared culture where we really want to get it right."

In addition, Sage used base LCFF funds to support key investments for all schools, including academic counselors in all secondary schools. Several leaders noted that these base investments helped ease the sense of loss for schools that experienced cuts in administrative staff. Low-unduplicated schools were told, "You're going to lose a half-time [assistant principal] but you're going to get counselors." As discussed in the following section, this perception of adequacy along with Sage's coherent organizational identity were key factors supporting the enactment of vertical equity in the district.

Although the overwhelming majority of Sage interviewees supported the new staffing allocation policy, not everyone was pleased with the redistributive approach. One school board member noted "some families"" concerns that district leaders "only care about the English learner, Latino students." He and others reportedly questioned "the arbitrary line that was drawn" when developing the staffing formula, resulting in frustration by schools that just missed the cutoff for receiving additional staff.

Sage's decision to allocate administrative staff based on unduplicated counts is illustrated in table 6, which presents changes in student-to-staff ratios in a sample of Sage and Annatto schools, selected based on their unduplicated 
TABLE 6

Changes in Student-to-Staff Ratios in Selected Schools Pre-LCFF (2012-13) and Post-LCFF (2016-17) (\%)

\begin{tabular}{|c|c|c|c|c|c|c|}
\hline & \multicolumn{2}{|c|}{ TEACHER } & \multicolumn{2}{|c|}{ ADMINISTRATOR } & \multicolumn{2}{|c|}{ PUPIL SERVICES } \\
\hline & Sage & Annatto & Sage & Annatto & Sage & Annatto \\
\hline \multicolumn{7}{|c|}{$>70 \%$ unduplicated: } \\
\hline Elementary & -9.8 & +9.39 & -46.3 & 0 & -46.73 & +99.2 \\
\hline Middle & +2.6 & -1.03 & -8.49 & -31.14 & -8.39 & -38.8 \\
\hline High & -5.3 & -12.88 & -5.36 & -16.38 & -43.22 & -27.21 \\
\hline \multicolumn{7}{|c|}{$30 \%-70 \%$ unduplicated: } \\
\hline Elementary & -.79 & +22.36 & -25.36 & -33.74 & -25.36 & -49.6 \\
\hline Middle & -16.98 & -4.65 & +35.48 & -56.22 & -32.26 & +31.34 \\
\hline High & +3.79 & -6.42 & -11.51 & +15.68 & -36.16 & +5.59 \\
\hline \multicolumn{7}{|c|}{$<30 \%$ unduplicated: } \\
\hline Elementary & +1.83 & $\ldots$ & +71.77 & .. & +9.41 & .. \\
\hline Middle & +2.26 & .. & +108.07 & 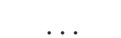 & -16.77 & 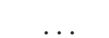 \\
\hline High & -5.3 & $\ldots$ & +25.84 & $\ldots$ & -49.58 & $\ldots$ \\
\hline
\end{tabular}

SOURCE.-California Department of Education.

NoTE.-Changes in ratios of students to teachers, administators, and pupil services personnel from 2012-13 to 2016-17 for six Annatto schools and nine Sage schools, selected by grade level (elementary, middle, or high) and unduplicated student percentages. Data prior to 2012 were not included, as California was in a recession during this time. No Annatto schools have $>30 \%$ unduplicated students. Increases in the ratio of student to teachers/administrators/pupil services staff are illustrated with a plus sign; decreases in ratio of students to teachers/administrators/pupil services staff are illustrated with a negative sign.

percentages and grade levels (elementary, middle, and high). The table shows the change in these ratios from 2012-13, before LCFF, to 2016-17, the year of this case study. In Sage, the three sampled low-unduplicated schools saw a sizable increase in their administrator-to-student ratio, indicating that, after LCFF implementation, privileged Sage schools lost administrators. Sage's highunduplicated schools, however, saw modest decreases in the student-toadministrator ratios, suggesting that these high-unduplicated schools slightly gained administrative support. Moreover, eight of the nine sampled Sage schools saw decreases in their ratio of student to pupil services staff, reflective of the decision to allocate counselors to all schools using base funding. In contrast, Annatto has no low-unduplicated schools, and changes in student-to-staff ratios do not clearly align with the distinction between high- and mid-unduplicated schools. This finding is consistent with Annatto's approach to hire new staff that served all schools and, when targeting its spending, to focus on programs rather than staff.

FEBRUARY 2019 


\section{Equity in California Education Finance Reform}

LCFF resource allocation in Annatto: Equalization, then targeted spending.--Leaders in Annatto were quite clear that LCFF funds could be used to benefit all schools, because, as noted, all schools had large shares of unduplicated students (due to the district's large LI population) and non-Title I schools were very close to the Title I qualifying threshold of $40 \%$ LI students. The superintendent, for example, described using LCFF "to equalize" funds for non-Title I schools in South Annatto. This approach aligns with Annatto participants' belief in equity as equal resources for all. To pursue this equalization while also realizing LCAP goals, Annatto increased professional development and program offerings across the district. According to the district budget and LCAP, Annatto allocated more than $70 \%$ of its LCFF supplemental and concentration dollars toward district-wide investments to increase the skills of existing faculty and staff in all schools and to hire additional district-level staff, such as instructional coaches who rotated their time across all schools. Some examples of these expenditures included advanced placement (AP) training for all secondary schools, expansion of career technical education in all schools, and training for Common Core standards and technology. These district-wide initiatives were intended to benefit all students, targeted and nontargeted. New staff were typically located in the district headquarters and rotated among the schools. For all schools, the district offered several types of counselors, support personnel, and programs associated with academic and social-emotional development; the district also covered administrative fees for various tests (e.g., AP, SAT) for all students.

Administrators at South Annatto schools, not surprisingly, appreciated the infusion of resources. One administrator said, "To have LCFF and the LCAP provide that is just so beneficial to our students because we don't have the resources that a Title I school has ... we have about an eighth of the budget." However, whereas 73\% of Annatto's student population is LI, only $20 \%$ are EL, and one administrator expressed concern that new staff members were not directed to serve ELs specifically: "Are we telling them you have to work with these EL kids to increase their improvement? No, we're not." This comment suggests that resources justified by the district's high unduplicated count may have focused on LI, but not EL, populations; from a transformative stance, this choice reflects a lack of consideration of intersectionality.

While Annatto administrators allocated large portions of their LCFF resources equally among schools, reflective of horizontal equity, they also differentiated some resources based on perceptions of needs. According to Annatto's LCAP, three schools with more than $85 \%$ unduplicated students received additional programs, including dual language curricula, a summer transition program for new students, and engineering electives. The use of both equalization and differentiation is consistent with Annatto's dual equity conceptions: equal resources for all, and greater resources for greater needs. 


\section{Factors Shaping Equity Conceptions and Resource Allocations}

Analyzing our data through the lens of sensemaking theory revealed that organizational identity and actors' perceptions of adequacy were key factors relating to equity conceptions and resource allocation decisions. We discuss these findings below.

\section{Organizational Identity and Goals}

Participants in Sage described an organizational identity that emphasized coherence and alignment, embodied in the district's strategic plan. In Annatto, however, interviewees discussed an organizational identity of division, characterized by two competing "sides" and lacking clear district goals. These organizational contexts were reflected in the single conception of equity in Sage and the dual conceptions of equity in Annatto.

Multiple Sage interviewees described coherence between values and actions: as one principal explained, "everything is seamless here." Every Sage interviewee referenced a strategic plan developed in the 2010s, which included a commitment to eliminate the "opportunity gap." The district's LCAP is tightly aligned to this strategic plan. The superintendent noted, "The organizational clarity and the laser-like focus [the strategic plan] created have been really powerful." In contrast, Annatto did not have a strategic plan. When asked to describe district goals, participants varied widely in their responses. One principal explained, "There are multiple goals for the district. There are different initiatives going on that don't always necessarily align.... Sometimes those things don't get addressed or there are too many that it makes it too challenging to get good at one of them." The absence of clear organizational goals appeared to create challenges for developing a district-wide understanding of equity in the context of LCFF.

Annatto participants described an organizational identity of division between North and South. A principal said, "We literally have railway tracks, the tale of two different sides of the tracks if you will." Participants described South Annatto as a white and Asian, middle-class community concerned about their schools' lack of Title I funds, and North Annatto as a Latinx, LI community critical of South Annatto's higher-quality school facilities. In the words of the teachers' union president: 'It's like the stepchild syndrome, 'Well, you get more than I do.' Then the brother or sister, 'Well, no you get more than I do.'" One administrator explained residents' racial prejudice toward North Annatto: "They say they're not racist, but 'I don't want my ... white, Asian, daughter, kid, son in a [North Annatto] school with 90\% Hispanics.'" This identity of division reflects historical 
and present dynamics of racial and socioeconomic stratification, illustrating assumptions from the transformative equity conception.

This perception of division is complicated by Annatto's demographics; schools in both sides of town enroll at least one-third unduplicated students due to the district's large LI population; thus, it is difficult to differentiate among schools in Annatto using LCFF's targeted groups. In contrast, Sage's demographics suggest a clearer divide between high- and low-unduplicated schools, facilitating a liberal vision of resource distribution based on needs.

\section{Perceptions of Adequacy as a Condition for Equity}

In both districts, participants explained that an adequate distribution of resources for all students could support a need-based equity goal. In Sage, many interviewees stated that a foundation of adequate resources for all schools made it easier to distribute greater resources to higher-need schools. The Sage superintendent said, "We need to distribute this in a way that schools can meet the basic needs. Then with the [supplemental grant] that's where we'll really give more services and staff to those schools with the higher needs." In Annatto, several participants suggested that South Annatto schools lacked adequate funding, and that this inadequacy demanded equal distributions of limited district resources. A central office administrator explained, "School adequacy, I think that that really is the elephant in the room. There lacks adequacy to fulfill all of our obligations."

These perceptions of adequacy reflect the per-pupil spending in each district. As a result of higher local property taxes, Sage has higher overall resources and greater per-pupil spending than Annatto. Annatto's perception of inadequate resources was also influenced by sharply declining enrollment, which district administrators attributed to competition with neighboring districts and private schools (Annatto does not have a charter school sector). In the words of the superintendent, "Declining enrollment is the biggest challenge. The district has been declining for the past ten years ... [it] continues to be a threat." In Annatto, inadequate resources were viewed as an impediment to vertical equity; thus, both districts suggest that adequacy may be a key condition for need-based resource distribution.

\section{Discussion and Conclusion}

Our study found that, in our case districts, leaders' conceptions of equity relate to their implementation of LCFF. Resource allocation decisions in Sage mirrored a consistent, organization-wide understanding of equity as greater resources for students with greater needs, whereas choices in Annatto reflected competing, individual notions of equity as both unequal and equal distributions of resources. 
Perceptions of (in)adequacy, organizational identities, and student demographics were important conditions relating to district actors' conceptions and policy enactment.

These findings suggest that, in implementing equity-based finance reform, local actors' beliefs and actions may differ from policy makers' expectations. In this case, LCFF reflects the liberal belief in distributing resources unequally to compensate for societal disadvantages, as well as the democratic liberal principle of high-performance outcomes. In Sage, a coherent, district-wide liberal vision and targeted resource allocation aligned with the vertical equity intent of LCFF. However, in Annatto, competing equity conceptions and a primarily district-wide resource allocation approach appear to diverge from LCFF goals. Sensemaking theory (Spillane et al. 2002; Weick et al. 2005) helps us understand why local actors' implementation may differ from policy makers' intent, as cognitive structures and local context are expected to influence district leaders' enactment of LCFF.

Our findings reveal several important implications for policy makers and practitioners seeking to promote vertical equity in school finance. First, echoing the findings of Malen et al. (2015), we observed that a perception of adequate funding may facilitate needs-based distributions, as even those students receiving fewer resources are still perceived as receiving adequate services. District leaders in Sage cited adequate funding as a support for their differentiated resource allocation, whereas in Annatto, a perception of inadequate funding for schools falling just below the Title I threshold informed their "reverse equity" approach to equalizing funding across the district. These concerns about inadequate funding are echoed in reports that California's per-pupil education spending falls below national averages; for example, one report ranked California forty-first in the nation in per-pupil spending in 2015-16 (Kaplan 2017). To support differentiated funding, our findings suggest a need for state and federal policies and budgets that ensure not only equitable but also adequate resources.

Second, our data show that coherent, district-wide understandings of equity may support vertical resource allocation. In Sage, participants suggested that the district's strategic plan played a crucial role in supporting a district-wide understanding of equity as greater resources for students with greater needs. Although some might argue that the state-mandated LCAP could serve as a strategic plan, the case of Annatto suggests that the LCAP may not be sufficient in supporting the coherent vision needed for differentiated resource allocation. It may benefit policy makers and local educators to consider how to develop strong organizational plans that include clear definitions of equity. A framework of equity conceptions, such as the one presented in this article, may be a helpful resource in guiding district actors in clarifying and building consensus around their equity assumptions. 
Finally, our findings suggest that a diverse population of "haves" and "havenots," as observed in Sage, may facilitate a liberal approach of providing additional resources to students considered disadvantaged. In contrast, the relatively limited socioeconomic diversity in Annatto appeared to impede a liberal vision. This raises questions about whether a democratic liberal or transformative approach might better support vertical equity in school districts serving overall LI populations. A democratic liberal conception could prompt district leaders to use student performance data to define need, allocating additional resources to support students who are struggling academically rather than based on students' background characteristics. A transformative conception could prompt district actors to interrogate processes that might maintain broader societal stratification, such as the disproportionate suspension of black and Latinx students; disparities in course access by race, socioeconomic status, and language background; or teachers' implicit biases. District actors could then consider how to allocate resources to mitigate such inequitable processes. In sum, democratic liberal and transformative conceptions may illuminate inequities that other approaches might miss, and these lenses may be helpful in furthering the goals of equity-oriented finance formulas such as LCFF.

Moving beyond the findings presented here, future research could continue to explore the development and implications of district leaders' equity conceptions. For instance, studies on the development and implementation of organizational plans could shed light on the construction of coherent, districtwide equity definitions. Research on districts with democratic liberal and transformative stances could illuminate the advantages and challenges of such views. In addition, researchers might consider how equity conceptions relate to other aspects of district policy beyond resource allocation, such as approaches to instructional improvement or accountability. In particular, researchers might consider how the engagement of community members beyond district leaders, as required by LCFF, could shape or be shaped by equity conceptions. For instance, a transformative conception might lead district actors to elevate the voices of historically marginalized community members, or perhaps the inclusion of these community members could advance transformative views.

Despite decades of policy efforts, inequities by race, socioeconomic status, and EL designation remain a pressing concern in $\mathrm{K}-12$ schools. Though policy makers and practitioners may profess a common goal of equity in education, it is likely that they disagree about what "equity" is, and these disagreements have important implications for the policies that shape students' educational experiences. Local actors' beliefs may be key in determining the success or failure of equity-oriented policy reforms. If we wish to promote equity in education, we must first ask what equity means. 


\section{Notes}

This study was made possible through the support of the William and Flora Hewlett Foundation, the Stuart Foundation, and the Kabcenell Foundation. We thank the members of the Local Control Funding Formula Research Collaborative, especially Julia Koppich and Tasminda Dhaliwal, for their support in data collection. We are grateful to Julie Posselt, Estela Bensimon, Julian Vasquez Heilig, Oscar JiménezCastellanos, and four anonymous reviewers for their feedback on this project. We sincerely appreciate the members of our two case study districts for sharing their time and experiences with us.

1. California uses student's free and reduced lunch eligibility to determine LI status.

2. Accountability policies have also used school funding as an incentive or sanction tied to student performance, such as in the system adopted in Texas in the early 1990s (Vasquez Heilig and Darling-Hammond 2008).

3. Although most categorical programs were eliminated, 14 were maintained. These included funds dedicated to the Special Education, Child Nutrition, Quality Education Improvement Act, among others.

4. At the time of writing, the state's new accountability system is under development and once implemented will likely affect the accountability aspects of LCFF, including the LGAP.

5. For more on the intent and early history of the policy, see Humphrey and Koppich (2014), Koppich et al. (2015), Menefee-Libey and Kerchner (2015), and Vasquez Heilig et al. (2014).

6. In this article, we discuss equity perspectives on the government distribution of resources; however, some libertarians (e.g., Nozick 1974) suggest that government should not be involved in distributing resources, which should instead be left to fair, market-based transactions.

7. Data from the US Census Bureau, American Community Survey, and city websites. Throughout the article, numbers have been slightly altered to maintain district anonymity, but basic proportions and scale remain true.

\section{References}

Allen, Carrie D., and William R. Penuel. 2015. "Studying Teachers' Sensemaking to Investigate Teachers' Responses to Professional Development Focused on New Standards." Zournal of Teacher Education 66 (2): 136-49.

Anyon, Yolanda, Anne Gregory, Susan Stone, Jordan Farrar, Jeffrey M. Jenson, Jeanette McQueen, Barbara Downing, Eldridge Greer, and John Simmons. 2016. "Restorative Interventions and School Discipline Sanctions in a Large Urban School District." American Educational Research Fournal 53 (6): 1663-97.

Baker, Bruce D., and Preston C. Green. 2005. "Tricks of the Trade: State Legislative Actions in School Finance Policy That Perpetuate Racial Disparities in the Post-Brown Era." American Fournal of Education 111 (3): 372-413. 


\section{Equity in California Education Finance Reform}

Bernal, Dolores Delgado. 2002. "Critical Race Theory, Latino Critical Theory, and Critical Raced-Gendered Epistemologies: Recognizing Students of Color as Holders and Creators of Knowledge." Oualitative Inquiry 8 (1): 105-26.

Bertrand, Melanie, and Julie A. Marsh. 2015. "Teachers' Sensemaking of Data and Implications for Equity." American Educational Research Fournal 52 (5): 861-93.

Bertrand, Melanie, Wendy Y. Perez, and John Rogers. 2015. "The Covert Mechanisms of Education Policy Discourse: Unmasking Policy Insiders' Discourses and Discursive Strategies in Upholding or Challenging Racism and Classism in Education." Education Policy Analysis Archives 23. doi:10.14507/epaa.v23.2068.

Bulkley, Katrina E. 2013. "Conceptions of Equity: How Influential Actors View a Contested Concept." Peabodv Fournal of Education 88 (1): 10-21.

Center for Education Policy Analysis. 2018. "The Educational Opportunity Monitoring Project: Racial and Ethnic Achievement Gaps." http://cepa.stanford.edu /educational-opportunity-monitoring-project/achievement-gaps/race/.

Ching, Cheryl D. 2017. "Constructing and Enacting Equity at a Community College." PhD diss., University of Southern California, Rossier School of Education.

Cho, Vincent, and Jeffrey C. Wayman. 2014. "Districts' Efforts for Data Use and Computer Data Systems: The Role of Sensemaking in System Use and Implementation." Teachers College Record 116 (2): 1-45.

Coburn, Cynthia E. 2001. "Collective Sensemaking about Reading: How Teachers Mediate Reading Policy in Their Professional Communities." Educational Evaluation and Policy Analvsis 23 (2): 145-70.

Coburn, Cynthia E. 2006. "Framing the Problem of Reading Instruction: Using Frame Analysis to Uncover the Microprocesses of Policy Implementation." American Educational Research Fournal 43 (3): 343-49.

Corcoran, Sean P., and William N. Evans. 2008. "Equity, Adequacy and the Evolving State Role in Education Finance." In Handbook of Research in Education Finance and Policy, ed. Helen F. Ladd and Edward B. Fiske. New York: Routledge.

Crenshaw, Kimberlé. 1991. "Mapping the Margins: Intersectionality, Identity Politics, and Violence against Women of Color." Stanford Law Review, 43 (6): 1241-99.

Darling-Hammond, Linda. 2004. "The Color Line in American Education: Race, Resources, and Student Achievement." Du Bois Review 1 (2): 213-46.

DeMatthews, David. 2015. "Making Sense of Social Justice Leadership: A Case Study of a Principal's Experiences to Create a More Inclusive School." Leadership and Policv in Schools 14 (2): 139-66.

Dewey, John. 1929. Democracy And Education: An Introduction to the Philosophy of Education. New York: Macmillan.

Dixson, Adrienne D., and Gelia K. Rousseau. 2005. "And We Still Are Not Saved: Critical Race Theory in Education Ten Years Later." Race Ethnicity and Education 8 (1): 7-27.

Dowd, A. C., and E. M. Bensimon. 2015. Engaging the "Race Question": Accountability and Equity in US Higher Education. Multicultural Education Series. New York: Teachers College Press.

Evans, A. E. 2007. "School Leaders and Their Sensemaking about Race and Demographic Change." Educational Administration Ouarterlv 43 (2): 159-88.

Farrell, Caitlin C., and Julie A. Marsh. 2016. "Metrics Matter How Properties and Perceptions of Data Shape Teachers' Instructional Responses." Educational Administration Ouarterly 52 (3): 423-62.

Fischel, William. 1996. "How Serrano Caused Proposition 13." Fournal of Law and Politics $12: 607-45$. 
Gándara, Patricia, and Russell W. Rumberger. 2009. "Immigration, Language, and Education: How Does Language Policy Structure Opportunity." Teachers College Record 111 (3): 750-82.

Gándara, Patricia C., and Ursula S. Aldana. 2014. "Who's Segregated Now? Latinos, Language, and the Future of Integrated Schools." Educational Administration Ouarterly 50 (5): 735-48.

Goldhaber, Dan, Lesley Lavery, and Roddy Theobald. 2015. "Uneven Playing Field? Assessing the Teacher Quality Gap between Advantaged and Disadvantaged Students." Educational Researcher 44 (5): 293-307.

Gonzalez, Norma, Luis C. Moll, Martha Floyd Tenery, Anna Rivera, Patricia Rendon, Raquel Gonzales, and Cathy Amanti. 1995. "Funds of Knowledge for Teaching in Latino Households." Urban Education 29 (4): 443-70.

Gordon, Jenny. 2005. "White on White: Researcher Reflexivity and the Logics of Privilege in White Schools Undertaking Reform." Urban Review 37 (4): 279 302.

Guiton, Gretchen, and Jeannie Oakes. 1995. "Opportunity to Learn and Conceptions of Educational Equality." Educational Evaluation and Policy Analvsis 17 (3): 323-36.

Gutmann, Amy. 1987. Democratic Education. Princeton, NJ: Princeton University Press.

Hall, Michelle. 2016. "Education Finance and the Politics of California Policymaking: A Case Study of the Local Control Funding Formula." PhD diss., University of Southern California, Rossier School of Education.

Halverson, Richard, Carolyn Kelley, and Steven Kimball. 2004. "Implementing Teacher Evaluation Systems: How Principals Make Sense of Complex Artifacts to Shape Local Instructional Practice." In Educational Administration, Policy, and Reform: Research and Measurement, ed. Wayne K. Hoy and Cecil Miskel. Charlotte, NC: Information Age.

Hansen, Janet S., Michelle Hall, Dominic Brewer, and Jane Hannaway. 2008. "The Role of Nongovernmental Organizations in Financing Public Schools." In Handbook of Research in Education Finance and Policy, ed. Helen F. Ladd and Margaret E. Goertz. Florence, KY: Routledge, Taylor \& Francis.

Harper, Shaun R., and Charles H. F. Davis III. 2012. "They (Don't) Care about Education: A Counternarrative on Black Male Students' Responses to Inequitable Schooling." Educational Foundations 26 (1-2): 103-20.

Herrnstein, Richard J., and Charles Murray. 2010. The Bell Curve: Intelligence and Class Structure in American Life. New York: Simon \& Schuster.

Honig, Meredith I., Nitya Venkateswaran, and Patricia McNeil. 2017. "Research Use as Learning: The Case of Fundamental Change in School District Central Offices." American Educational Research Fournal 54 (5): 938-71.

Humphrey, Daniel G., and Julia E. Koppich. 2014. "Toward a Grand Vision: Early Implementation of California's Local Control Funding Formula." Policy Analysis for California Education, Stanford Graduate School of Education, Stanford, CA.

Humphrey, Daniel, Julia Koppich, Magaly Lavadenz, Julie Marsh, Jennifer O’Day, David Plank, Laura Stokes, and Michelle Hall. 2017. "Paving the Way to Equity and Coherence? The Local Control Funding Formula in Year 3." Policy Analysis for California Education, Stanford Graduate School of Education, Stanford, CA.

Ingle, Kyle, Stacey Rutledge, and Jennifer Bishop. 2011. "Context Matters: Principals' Sensemaking of Teacher Hiring and On-the-Job Performance." Zournal of Educational Administration and History 49 (5): 579-610. 


\section{Equity in California Education Finance Reform}

Kana'iaupuni, Shawn Malia, Brandon Ledward, and Nolan Malone. 2017. "Mohala i ka wai: Cultural Advantage as a Framework for Indigenous Culture-Based Education and Student Outcomes." American Educational Research fournal 54 (1 suppl.): 31 1S-339S.

Kaplan,Jonathan. 2017. "California's Support for K-12 Education Is Improving, but Still Lags the Nation." California Budget and Policy Center, Sacramento, CA.

Kirst, Michael, Margaret Goertz, and Allan Odden. 2007. "Evolution of California School Finance with Implications from Other States." Center for Education Policy Analysis, Stanford Graduate School of Education, Stanford, CA.

Koppich, Julia E., Daniel C. Humphrey, and Julie A. Marsh. 2015. Two Years of California's Local Control Funding Formula: Time to Reaffirm the Grand Vision. Berkeley: Policy Analysis for California Education.

Ladd, Helen F., Rosemary Chalk, and Janet S. Hansen. 1999. Equity and Adequacy in Education Finance: Issues and Perspectives. Washington, DC: National Academies.

Lakes, Richard D., and Martha K. Donovan. 2017. "The International Baccalaureate Career Programme: A Case Study of College and Career Readiness Policy Goals." Fournal of Education Policy 33 (1): 62-84.

Malen, Betty, Justin Dayhoff, Laura Egan, and Robert G. Croninger. 2015. "The Challenges of Advancing Fiscal Equity in a Resource-Strained Context." Educational Policv 31 (5): 615-42.

Manwaring, Robert L. 2005. "Proposition 98 Primer." Legislative Analyst's Office, Sacramento, CA.

McKown, Clark, and Rhona S. Weinstein. 2008. "Teacher Expectations, Classroom Context, and the Achievement Gap." Zournal of School Psvchology 46 (3): 235-61.

Mehta, Jal. 2013. "How Paradigms Create Politics: The Transformation of American Educational Policy, 1980-2001." American Educational Research Fournal 50 (2): 285-324.

Menefee-Libey, David, and Charles Taylor Kerchner. 2015. "California's First Year with Local Control Finance and Accountability." Education Policy Analysis Archives 23. doi:10.14507/epaa.v23.2022.

Miles, Matthew B., and A. Michael Huberman. 1994. Qualitative Data Analysis. Thousand Oaks, CA: Sage.

Mills, Jean Helms, Amy Thurlow, and Albert J. Mills. 2010. "Making Sense of Sensemaking: The Critical Sensemaking Approach." Oualitative Research in Organizations and Management 5 (2): 182-95.

National Center for Education Statistics. 2017. "The Condition of Education: Educational Attainment of Young Adults." National Center for Education Statistics, https:// nces.ed.gov/programs/coe/indicator_caa.asp.

Ng, Jennifer C., Sharon S. Lee, and Yoon K. Pak. 2007. "Contesting the Model Minority and Perpetual Foreigner Stereotypes: A Critical Review of Literature on Asian Americans in Education." Review of Research in Education 31 (1): 95-130.

Nozick, Robert. 1974. Anarchy, State, and Utopia. New York: Basic.

Oakes, Jeannie, and Gretchen Guiton. 1995. "Matchmaking: The Dynamics of High School Tracking Decisions." American Educational Research Fournal 32 (1): 3-33.

Odden, Allan, and Lawrence Picus. 2014. School Finance: A Policy Perspective. 5th ed. New York: McGraw-Hill Higher Education.

Orfield, Gary, and Erica Frankenberg. 2014. Brown at 60: Great Progress, a Long Retreat and an Uncertain Future. Los Angeles: University of California Los Angeles, Civil Rights Project.

Park, Vicki, and Amanda Datnow. 2017. "Ability Grouping and Differentiated Instruction in an Era of Data-Driven Decision Making." American Fournal of Education 123 (2): 281-306. 
Peshkin, Alan. 1988. "In Search of Subjectivity—One's Own." Educational Researcher 17 (7): $17-21$.

Pettit, Stacie Kae. 2011. "Teachers' Beliefs about English Language Learners in the Mainstream Classroom: A Review of the Literature." International Multilingual Research Zoumal 5 (2): 123-47.

Piaget,Jean, and Barbel Inhelder. 1969. The Psychology of the Child, 2nd ed. New York: Basic.

Rawls, John. 2009. A Theory of Justice. Cambridge, MA: Harvard University Press.

Reardon, Sean F. 2011. "The Widening Academic Achievement Gap between the Rich and Poor: New Evidence and Possible Explanations." In Whither Opportunity? Rising Inequality and the Uncertain Life Chances of Low-Income Children, ed. R. Murnane and G. Duncan. New York: Sage Foundation.

Rigby, Jessica G. 2015. "Principals' Sensemaking and Enactment of Teacher Evaluation." Zournal of Educational Administration and Historv 53 (3): 374-92.

Rose, Heather, Jon Sonstelie, Margaret Weston, and Hans P. Johnson. 2010. "Pathways for School Finance in California." Public Policy Institute of California, San Francisco.

Saldaña, Johnny. 2013. The Coding Manual for Qualitative Researchers. 2nd ed. Thousand Oaks, CA: Sage.

Silva, Fabio, and Jon Sonstelie. 1995. "Did Serrano Cause a Decline in School Spending?" National Tax foumal 48 (2): 199-209.

Sleegers, Peter, Hartger Wassink, Klaas van Veen, and Jeroen Imants. 2009. "School Leaders' Problem Framing: A Sense-Making Approach to Problem-Solving Processes of Beginning School Leaders." Leadership and Policv in Schools 8 (2): 152-72.

Solórzano, Daniel G., and Dolores Delgado Bernal. 2001. "Examining Transformational Resistance through a Critical Race and LatCrit Theory Framework: Chicana and Chicano Students in an Urban Context." Urban Education 36 (3): 308-42.

Solórzano, Daniel G., and Armida Ornelas. 2002. "A Critical Race Analysis of Advanced Placement Classes: A Case of Educational Inequality." Fournal of Latinos and Education 1 (4): 215-29.

Solórzano, Daniel G., and Tara J. Yosso. 2002. "Critical Race Methodology: CounterStorytelling as an Analytical Framework for Education Research.” Oualitative Inquiry 8 (1): 23-44.

Sonstelie, Jon. 2001. "Is There a Better Response to Serrano?" In School Finance and Califormia's Master Plan for Education, ed. Jon Sonstelie and Peter Richardson. San Francisco: Public Policy Institute of California.

Sonstelie, Jon, Eric Brunner, and Kenneth Arton. 2000. For Better or For Worse? School Finance Reform in Califormia. San Francisco: Public Policy Institute of California.

Spillane, James P. 2000. "Cognition and Policy Implementation: District Policymakers and the Reform of Mathematics Education." Coonition and Instruction 18 (2): 141-79.

Spillane, James P. 2012. "Data in Practice: Conceptualizing the Data-Based DecisionMaking Phenomena." American Foumal of Education 118 (2): 113-41.

Spillane, James P., Brian J. Reiser, and Todd Reimer. 2002. "Policy Implementation and Cognition: Reframing and Refocusing Implementation Research." Review of Educational Research 72 (3): 387-431.

Strauss, Valerie. 2013. "California's Gov. Brown Blasts State, Federal Education Policy." Washington Post, January 24, https://www.washingtonpost.com/news/answer-sheet /wp/2013/01/24/californias-gov-brown-blasts-state-federal-education-policy/.

Trujillo, Tina M. 2013. "The Politics of District Instructional Policy Formation: Compromising Equity and Rigor." Educational Policy 27 (3): 531-59.

FEBRUARY 2019 
Umansky, Ilana M. 2016. "To Be or Not to Be EL: An Examination of the Impact of Classifying Students as English Learners." Educational Evaluation and Policy Analvsis 38 (4): 714-37.

Unterhalter, Elaine. 2009. "What Is Equity in Education? Reflections from the Capability Approach." Studies in Philosobhv and Education 28 (5): 415-24.

Vasquez Heilig, Julian, and Linda Darling-Hammond. 2008. "Accountability TexasStyle: The Progress and Learning of Urban Minority Students in a High-Stakes Testing Context." Educational Evaluation and Policy Analvsis 30 (2): 75-110.

Vasquez Heilig, Julian, Derrick R. Ward, Eric Weisman, and Heather Cole. 2014. "Community-Based School Finance and Accountability." Urban Education 49 (8): 871 94.

Warikoo, Natasha, Stacey Sinclair, Jessica Fei, and Drew Jacoby-Senghor. 2016. "Examining Racial Bias in Education: A New Approach." Educational Researcher 45 (9): 50814.

Weick, Karl E. 1995. Sensemaking in Organizations. Thousand Oaks, CA: Sage.

Weick, Karl E., Kathleen M. Sutcliffe, and David Obstfeld. 2005. "Organizing and the Process of Sensemaking." Organization Science 16 (4): 409-21.

Weston, Margaret. 2011. Rethinking the State-Local Relationship: K-12 Education. San Francisco: Public Policy Institute of California.

Yin, Robert K. 2014. Case Study Research: Design and Methods. Thousand Oaks, CA: Sage.

Yosso, Tara J. 2005. "Whose Culture Has Capital? A Critical Race Theory Discussion of Community Cultural Wealth." Race Ethnicity and Education 8 (1): 69-91. 